\title{
« Hishām b. al-Ḥakam (d. 179/795) and his doctrine of the imām's knowledge ». Journal of Semitic Studies, XLVIII/1, (2003), pp. 71-108.
}

\section{Antoine Borrut}

\section{(2) OpenEdition}

1 Journals

Édition électronique

URL : http://journals.openedition.org/abstractairanica/2403

ISSN : 1961-960X

Éditeur :

CNRS (UMR 7528 Mondes iraniens et indiens), Éditions de l'IFRI

Édition imprimée

Date de publication : 15 mai 2005

ISSN : 0240-8910

\section{Référence électronique}

Antoine Borrut, « « Hishām b. al-Hakam (d. 179/795) and his doctrine of the imām's knowledge ». Journal of Semitic Studies, XLVIII/1, (2003), pp. 71-108. », Abstracta Iranica [En ligne], Volume 26 | 2005, document 301, mis en ligne le 07 décembre 2005, consulté le 25 septembre 2020. URL : http:// journals.openedition.org/abstractairanica/2403

Ce document a été généré automatiquement le 25 septembre 2020.

Tous droits réservés 


\title{
« Hishām b. al-Ḥakam (d. 179/795) and his doctrine of the imām's knowledge ». Journal of Semitic Studies, XLVIII/1, (2003), pp. 71-108.
}

\author{
Antoine Borrut
}

L'A. propose une importante discussion hérésiographique sur la question de la connaissance de l'imam dans le chiisme imamite. Hišām b. al-Ḥakam est connu pour avoir joué un rôle clef dans l'élaboration de cette doctrine; l'étude détaillée de sa théorie s'oppose nettement à la théorie ésotérique qui s'est imposée ensuite dans le chiisme imamite classique. En analysant un texte d'Hišām (le Kitāb iHtilāâf al-nās fillimāma), préservé dans l'ouvrage plus tardif de Nawbahtīi, l'A. démontre que ce dernier défendit la thèse de l'inspiration de l'imam, en s'efforçant de surcroît de la faire passer pour la doctrine originelle. Les évidences documentaires infirment cette hypothèse, en mettant en exergue que la conception d'Hišām repose exclusivement sur la transmission du savoir et sur la (ișma, rendant l'imam infaillible, préservant ainsi l'intégrité de la révélation prophétique. En dépit des divergences de vue entre les deux auteurs, on se reportera en complément aux travaux de M. A. Amir-Moezzi, notamment «Fin du Temps et Retour à l'Origine (Aspects de l'imamologie duodécimaine VI)», in : M. Garcia-Arenal (dir.), Mahdisme et Millénarisme en Islam, Revue des Études des Mondes Musulmans et de la Méditerranée, 91-92-93-94, (2000), pp. 53-72, qui offre une abondante bibliographie. 
INDEX

Thèmes : 7. Islam

nompropre Hišām b. al-Ḥakam, NawbaHtīi

\section{AUTEURS}

ANTOINE BORRUT

IFPO - Damas 